Przegląd Badań Edukacyjnych Educational Studies Review

ISSN 1895-4308

nr 25 (2/2017), s. 163-182

ORYGINALNE ARTYKULY BADAWCZE

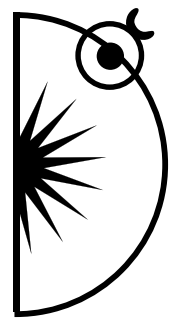

Beata Maria Nowak

Akademia im. Jana Długosza w Częstochowie, e-mail: nowak.beata.maria@gmail.com

\title{
Poczucie lokalizacji kontroli u skazanych powracających do przestępstwa a postrzeganie przez nich własnych rodzin pochodzenia
}

DOI: http://dx.doi.org/10.12775/PBE.2017.025

\section{Locus of Control in Offenders Returning to Crime and Their Perception of Their Own Families of Origin}

\begin{abstract}
Subjectively perceived locus of control provides information on the extent of individual adaptation and how the individual deals with difficulties in various spheres of life. Learning to perceive the connection between our behavior, its positive and negative effects and taking measures to achieve the desired effect is the result of repeated experience. Family factors are crucial for shaping the locus of control, i.e. parental attitude, the relationship between a child and their parents and the child's experience in various socio-educational situations. This article presents the results of a survey on locus of control in penitentiary recidivists and their perception of selected aspects of upbringing in their families of origin. The survey uses J.B. Rotter's Locus of Control Scale translated by L. Drwal's, and the author's own questionnaire. The participants of the survey were 245 recidivists and penitentiary multi-recidivist offenders in two types of penitentiaries - semi-open and closed. It was established that the penitentiary recidivists have an external locus of control. There were, however, no significant associations between locus of control and a type of family of origin as well as the number of repeated offences. Penitentiary recidivists perceive their own families of origin as having numerous problems and the characteristics which were probably the cause of the formation of an external locus of control (i.a. unemployment, poverty, alcoholism in the family and helplessness or passivity of parents in the face of growing problems, dominant, parental
\end{abstract}


attitude with an adverse effect on upbringing: 'lukewarm' - indifferent and rejecting, and 'unstable' - inconsistent attitude. In addition, the survey showed that the higher the level of education of the person imprisoned, the worse the relationship with their parents. The survey results indicate the need for providing both social and social development support for the families with penitentiary problems. It is also desirable to take preventive, psycho-educational and resocialisation actions, focused on reorienting LOC of penitentiary recidivists from an external to an internal one. In addition, there should be parenting skills workshops and certain measures in the field of shaping parental attitudes should be taken in order to prepare inmates for living outside prison bars.

Key words: locus of control, penitentiary recidivists, family of origin, parental attitude, social readaptation

\section{Wprowadzenie}

Etiologia powstawania zaburzeń zachowania oraz przestępczości nieletnich wskazuje na znaczący udział czynników rodzinnych w procesie socjalizacji pierwotnej - procesie decydującym o efektach radzenia sobie w dorosłości w różnorakich sytuacjach społecznych. Rezultaty badań podłużnych wskazują jednoznacznie, że eksternalizacyjne zachowania rodziców (np. przejawy agresji, przeciwstawianie się i opór wobec otoczenia, buntowniczość, destruktywność, antyspołeczność), stanowią czynnik inicjujący zachowania przestępcze dzieci oraz wpływają znacznie na ich trwałość (Capaldi, Pears, Kerer, Owen, 2008). W wyniku warunkowania lub uczenia się, prowadzą do zaburzeń emocjonalnych i nieprawidłowej krystalizacji struktur poznawczych. Znaczenie kontrsocjalizacyjne przypisywane jest także takim czynnikom środowiska rodzinnego jak: rozkład ról społecznych w rodzinie, styl wychowania, cechy osobowości i stan zdrowia członków rodziny oraz siła więzi wewnątrzrodzinnych (Davis, 2007; Thornberry, 2005). Z powstawaniem zachowań przestępczych powiązana jest również zaburzona struktura rodziny oraz niewłaściwe postawy rodzicielskie, a przede wszystkim obojętność i nadopiekuńczość (Barnow, Schuckit, Lucht i in., 2002). Ponieważ rodzice na wczesnych etapach rozwoju dziecka stanowią podstawowe źródło wzmocnień, to postawy rodzicielskie (Rode, 2013), jak również miejsce w rodzinie oraz doświadczanie różnorakich sytuacji społeczno - wychowawczych mają duże znaczenie dla kształtowania się u niego poczucia umiejscowienia kontroli.

W sytuacje ryzyka społecznego, skutkującego niedostosowaniem społecznym i demoralizacją, wikłają się najczęściej dzieci wychowywane w rodzinach wieloproblemowych i/lub patologicznych, które są poddawane wpływom 
poprzez naśladownictwo rodzinnych wzorów myślenia i zachowania, często sprzecznych z zasadami i normami społecznymi. Dzieci wychowane w tego typu rodzinach, w dorosłości wykazują niski poziom kompetencji życiowych oraz powielają dysfunkcje i patologie rodzinne. Nie radząc sobie z problemami stosują najczęściej emocjonalne i/lub unikowe strategie radzenia sobie, a wiele z nich wchodzi na ścieżkę kariery przestępczej.

\section{Poczucie umiejscowienia kontroli (LOC - Locus of Control)}

Subiektywnie odczuwane ulokowanie sprawstwa zdarzeń jest istotne dla efektywności działań podejmowanych przez człowieka w sytuacjach społecznych. Twórca teorii poczucia kontroli wzmocnień J.B. Rotter (1966) przyjął, że kontrola jest mechanizmem wyuczonym, związanym z warunkowaniem instrumentalnym. Na skutek powtarzających się doświadczeń człowiek uczy się dostrzegać związek między swoim zachowaniem a jego pozytywnymi i negatywnymi skutkami, podejmując aktywność w celu osiągnięcia pożądanego efektu. Generalizuje je, a następnie - w zależności od zaistniałej sytuacji - buduje określone oczekiwania. W sytuacjach nowych oczekiwania są uogólnione, zaś w znanych - zgodne z oczekiwaniami typowymi dla danej sytuacji. Poczucie kontroli ujmowane jest przez Rottera dwojako: jako specyficzna właściwość osobowości (wymiar warunkujący sposób odbierania, przetwarzania informacji i zachowania się w różnych sytuacjach) oraz jako konstrukt poznawczy, wyrażający się w przekonaniu, że na bazie minionych doświadczeń można wyjaśniać zdarzenia aktualne oraz determinujący ludzkie zachowania (za: Kościelak, 2010).

Poczucie lokalizacji kontroli ${ }^{1}$ dostarcza informacji o stopniu przystosowania jednostki i jej sposobach radzenia sobie w różnych sferach życia. Kształtowanie jednego z biegunów poczucia kontroli (wewnętrznego lub zewnętrznego) rozpoczyna się dość wcześnie i powiązane jest z rozwojem poznawczym oraz społeczno - emocjonalnym (Szmigielska, 1996), zaś w jego percepcji decydującą rolę odgrywają przeszłe doświadczenia (Bandura, 1977, s. 194; Rotter 1966, s. 2). Wewnętrzne poczucie kontroli kształtuje się w wyniku częstego doświadczania sytuacji sprawowania kontroli nad wynikami własnych działań. Osoby wewnątrzsterowne są bardziej sprawne i efektywne oraz dojrzalsze emocjonalnie i społecznie - mają wyższą samoocenę (Nowicki, Strickland,

${ }^{1} \mathrm{Z}$ uwagi na obecność w literaturze kilku przekładów angielskiego terminu locus of control na język polski, w niniejszym opracowaniu termin poczucie umiejscowienia kontroli jest stosowany zamiennie z terminem poczucie lokalizacji kontroli. 
1973, s. 40) oraz bardziej realny obraz własnej osoby (Maqsud, 1980), wyższy stopień samoakceptacji i samodzielności, niższy poziom niepokoju, mniejszą skłonność do załamań psychicznych, a zatem lepiej przystosowują się do otaczającego świata oraz pełniej realizują własny rozwój. Osoby z LOC wewnętrznym prowadzą najczęściej aktywny styl życia, dbają o zdrowie, stosują się do zaleceń profilaktycznych, a także częściej i łatwiej zrywają z uzależnieniami (Krasowicz, Kurzyp-Wojnarska, 1987). Lepiej radzą sobie ze stresem, a w sytuacjach konfliktowych rzadziej stosują agresję, gdyż dysponują bogatszym wobec niej zestawem zachowań alternatywnych (Lobo Antunes, Ahlin, 2014). Jednakże w sytuacjach nieuchronności zdarzeń, osoby przejawiające nadmierne, często nierealistyczne przekonania o własnych możliwościach i kontroli, frustrują się i zachowują agresywnie (Strzelczyk, 2010). Z kolei poczucie kontroli zewnętrznej krystalizuje się w efekcie przekonania jednostki, że wyniki jej działań, zarówno sukcesy, jak i porażki zależne są od czynników losowych, innych osób czy instytucji. Osoby z LOC zewnętrznym postrzegają świat jako miejsce im nieprzyjazne i w porównaniu z osobami wewnątrzsterownymi, cechują się wyższym poczuciem niepokoju oraz niższą samooceną. Nie radzą sobie z problemami życiowymi, a w sytuacjach kryzysowych wykazują bierność lub stosują strategie unikowe - wykonują czynności zastępcze obniżające napięcie emocjonalne (Horner, 1996). Reagują często agresją lub autoagresją oraz wykazują skłonności do zachowań konfliktowych (Borecka-Bernat, 2014). Osoby zewnątrzsterowne zwykle są podporządkowane, zależne od innych ludzi lub zdarzeń, konformistyczne, nieaktywne społecznie, sterowane przez innych i sterujące innymi (np. swoimi dziećmi). Są zamknięte na odmienne poglądy, skłonne do uprzedzeń, stereotypowe w działaniach, a ponieważ mają niskie poczucie własnej wartości i wysokie poczucie lęku, są podatne na perswazję oraz kierowanie ich rozwojem i postępowaniem (Krasowicz, Kurzyp-Wojnarska, 1987).

Między poczuciem umiejscowienia kontroli a potrzebami, lękiem i mechanizmami obronnymi występują istotne zależności. Z LOC wewnętrznym i niskim niepokojem współwystępuje większe nasilenie mechanizmu reakcji upozorowanej, wyparcia i intelektualizacji niż w przypadku zewnątrzsterowności, przy czym u osób z LOC zewnętrznym oraz podwyższonym niepokojem, zwątpienie może być efektem treningu bezradności, jakiego doświadczyły one w swoim życiu. Potrzeby o charakterze społecznym, takie jak: afiliacji, autonomii, miłości i opieki (oparcia) oraz wrogości wobec innych (agresji), najmniej różnicują osoby zewnątrz- i wewnątrzsterowne (Chaim, 1996). Wewnętrzny LOC sprzyja adaptacji psychologicznej - podtrzymuje orientację na działanie 
(warunkuje realizację celów) oraz pozwala radzić sobie z psychologicznymi skutkami traumatycznych wydarzeń (Krasowicz, Kurzyp-Wojnarska, 1987, s. 221).

Poza procesem rozwoju indywidualnego opierającego się na uczeniu się w rozumieniu psychologicznym (gromadzeniu doświadczeń i subiektywnym postrzeganiu własnego wpływu na rezultaty swoich zachowań), poczucie umiejscowienia kontroli determinowane jest także czynnikami środowiskowymi: socjalnymi oraz oddziaływaniami intencjonalnymi - metodami wychowawczymi czy też technikami kształcenia, stosowanymi w trakcie edukacji szkolnej (Nowak, Krawczyk, 2014). Wewnątrzsterowność charakteryzuje osoby, które w procesie socjalizacji miały możliwość poznawania określonych stanów rzeczy oraz wpływania na otaczającą ich rzeczywistość. Duże znaczenie w rozwoju wewnętrznego poczucia kontroli przypisywane jest między innymi organizowaniu sytuacji wychowawczych umożliwiających dokonywanie wyborów. Na rozwój zewnątrzsterowności znaczący wpływ mają natomiast negatywne czynniki rodzinne, a zwłaszcza rygor oraz zmienność wymagań stawianych przez rodziców lub wychowawców (Nowicki, Strickland, 1973; Horner, 1996).

\section{Poczucie umiejscowienia kontroli u skazanych - przegląd badań}

W licznych badaniach lokalizacja kontroli rozpatrywana jest jako determinanta zachowań przestępczych. Wykazano, że związek z tego typu zachowaniami ma zewnętrzne poczucie umiejscowienia kontroli, a zachowania niezgodne z normami społecznymi aktywowane są przekonaniem, że czynniki zewnętrzne sprawują kontrolę nad osiąganiem sukcesów życiowych, co prowadzi do obniżenia poczucia własnej wartości (Blatier, 2000).

Analizy empiryczne w zakresie poczucia umiejscowienia kontroli u skazanych na karę izolacji więziennej przeprowadziła między innymi K. Strzelczyk (2010, s. 84), która poddała badaniu trzy grupy osadzonych: uzależnionych od alkoholu, od narkotyków i nieuzależnionych. Badanie wykazało, że wszystkich badanych cechuje zewnętrzna lokalizacja kontroli (brak różnic międzygrupowych). Ponadto stwierdzono, że LOC zewnętrzny koreluje pozytywnie z poczuciem bezradności, które pojawia się u skazanych na skutek wysokiego nasilenia poczucia przypadkowości zdarzeń oraz utraty kontroli w warunkach izolacyjnych. Odnotowano także dodatnią korelację między poczuciem przypadkowości zdarzeń, a objawami psychicznymi o charakterze psychotycznym: poczucie, że jest się obserwowanym i poczucie, że jest się śledzonym. Badani więźniowie wskazywali na istotne trudności (przeszkody w realizacji celów), 
które pojawiały się w ich życiu jeszcze przed osadzeniem w zakładzie karnym. Związane były one głównie $\mathrm{z}$ brakiem umiejętności radzenia sobie z podstawowymi problemami życia codziennego oraz poczuciem zagrożenia i lęku (s. 86).

Badania przeprowadzone przez L. Contreras, V. Molinę i M. Del Carmen Cano (2011) dowiodły z kolei, że zewnętrzna lokalizacja kontroli pełni funkcję pośredniczącą pomiędzy powrotnością do przestępstwa a objawami nieprzystosowania (niski poziom kompetencji społecznych, problemy w radzeniu sobie ze stresem, słaba samokontrola, niska tolerancja na frustrację) oraz dysfunkcją/ patologią środowiska rodzinnego (m.in. rozpad rodziny, uzależnienia, niskie dochody). Wykazano również, że doświadczanie sytuacji niekontrolowanych (np. udział w katastrofie komunikacyjnej, śmierć osoby bliskiej czy osadzenie w zakładzie karnym) oraz sposób ich wyjaśniania ma związek z pojawieniem się wyuczonej bezradności i depresją (Maier, Seligman, 1976). Co więcej, sytuacje nietypowe aktywują poszukiwanie atrybucyjne (Meyer et al., 1997, s. 258), przy czym do podjęcia próby lokalizacji przyczyn zaistnienia danego zdarzenia bardziej skłania porażka niż sukces (Weiner, 1985; Wong, Weiner, 1981, s. 661).

Poczucie umiejscowienia kontroli jest zmienną wyjaśniającą również w badaniach nad agresją. Dotyczy to sytuacji występowania zachowania agresywnego u osób wykazujących jednocześnie niski poziom samooceny, wysoki makiawelizm (Andreou, 2000; Wallace, Barry, Zeigler-Hill, Green, 2012) oraz słabe poczucie refleksyjności i koherencji (Turecka, 2005). Wyniki badań wykonanych przez E. Bowena i E.A. Gilchrista (2004) wskazują, że interpretacja czynów sprawców przemocy domowej oparta jest na przekonaniu, że ich problemy są efektem działań innych ludzi lub zrządzenia losu. Polskie badanie nad poczuciem lokalizacji kontroli u sprawców przestępstw agresywnych autorstwa K. Belniak (2014) wykazało ponadto, że osoby te cechuje wysokie poczucie kontroli zewnętrznej oraz niskie poczucie sprawczości. Więźniowie włączeni do podkultur więziennych wykazują większe nasilenie LOC wewnętrznego, gdyż zajmowanie silnej pozycji w grupie daje im poczucie kontroli większe, niż mają pozostali osadzeni. W sytuacji niepowodzenia więźniowie z LOC wewnętrznym nadmiernie się krytykują, natomiast w przypadku sukcesu nadmiernie go eksponują. Mają potrzebę ciągłego kontrolowania sytuacji, co skutkuje zachowaniami agresywnymi w przypadku poczucia utraty kontroli. Większość skazanych z LOC zewnętrznym wykazuje większą niezgodność między ,ja realnym" a ,ja idealnym" niż skazani z LOC wewnętrznym. Skazani zewnątrzsterowni odczuwają trudności $\mathrm{w}$ radzeniu sobie w sytuacjach problemowych z uwagi na deficyty kompetencyjne oraz podatność na manipulację. Przejawiają 
także więcej objawów niedostosowania emocjonalnego i wyższy poziom lęku od skazanych wewnątrzsterownych (Belniak, 2014). Nie stwierdzono natomiast różnic w tym zakresie pomiędzy recydywistami wielokrotnymi, a skazanymi po raz pierwszy (Bowen, Gilchrist, Beech, 2005). Ustalono także, że na obniżone poczucie sprawstwa wpływa doświadczanie sytuacji trudnych przed i w trakcie pobytu w zakładzie karnym. W trakcie odbywania kary izolacji więziennej, u osadzonych następuje spadek nasilenia poczucia kontroli wewnętrznej (Turecka, 2005), gdyż życie więzienne sprzyja kształtowaniu się postaw charakterystycznych dla LOC zewnętrznego, umożliwiającego lepsze przystosowanie do warunków izolacyjnych, a tym samym zabezpieczającego pozytywną samoocenę.

Interesujące badania przeprowadzili J.E. Terelak i M. Steckiewicz (2007). Wykazały one, że osadzeni posiadający LOC zewnętrzny, w większym stopniu preferują styl radzenia sobie ze stresem skoncentrowanym na emocjach niż więźniowie z LOC wewnętrznym. Skupiają się na sobie i własnych przeżyciach emocjonalnych (lęk, złość, frustracja, bunt). Ponieważ nie widzą możliwości zaradzenia sytuacji opresyjnej, w której się znaleźli, przejawiają tendencję do myślenia życzeniowego i fantazjowania. Osadzeni zewnątrzsterowni częściej stosują styl skoncentrowany na unikaniu niż więźniowie o wewnętrznym poczuciu kontroli. Przyjmują postawę bierną, angażując się w czynności zastępcze (m.in. sen, myślenie o rzeczach przyjemnych czy oglądanie telewizji).

W niniejszym artykule przedstawiony został zaledwie fragment badania, będący częścią wieloaspektowych poszukiwań empirycznych nad porażką readaptacyjną doświadczaną przez recydywistów penitencjarnych, dotyczący ich poczucia umiejscowienia kontroli oraz postrzegania własnych rodzin pochodzenia.

\section{Procedura i wyniki badań własnych}

Pojęcie recydywy penitencjarnej odnosi się do wszystkich skazanych za przestępstwo umyślne na karę pozbawienia wolności lub zastępczą karę pozbawienia wolności oraz skazanych za wykroczenia umyślne na karę aresztu lub zastępczą karę aresztu, którzy uprzednio już odbywali takie kary (art. $86 \S 1$ k.k.w.). Powiązane jest to z art. $64 \S 2$ k.k. - jeżeli po odbyciu co najmniej 6 miesięcy kary, sprawca skazany za przestępstwo umyślne na karę pozbawienia wolności popełnia w ciągu 5 lat umyślne przestępstwo podobne do przestępstwa, za które był już skazany, sąd może mu wymierzyć karę przewidzianą w wysokości do górnej granicy ustawowego zagrożenia zwiększonego o połowę. Zatem, w uję- 
ciu jurydycznym nie wszyscy przestępcy stają się recydywistami penitencjarnymi, jednakże w ujęciu kryminologicznym jest nim każdy recydywista, zarówno jurydyczny, jak i penitencjarny (za: Szczepanik, 2015, s. 19).

Zastanawiając się nad przyczynami porażki readaptacyjnej doświadczanej przez osoby skazane i biorąc pod uwagę znaczący udział poczucia kontroli w kreowaniu i przebiegu życia ludzkiego, zaprojektowałam badanie ukierunkowane na identyfikację poczucia umiejscowienia kontroli u recydywistów penitencjarnych (jednokrotnych i wielokrotnych, osadzonych w zakładach karnych typu półotwartego i zamkniętego) oraz postrzeganie przez nich wybranych cech ich rodzin pochodzenia (typ rodziny oraz jej sytuacja materialna, postawy wychowawcze rodziców i relacje osadzonych z rodzicami). W tym miejscu pragnę podkreślić, że, w penetracji rodzinnych uwarunkowań poczucia lokalizacji kontroli u osób dorosłych, powracających do przestępstwa, zasadne byłoby poszukiwanie korelacji między dominującym u nich poczuciem umiejscowienia kontroli a cechami ich rodziców i rodzin, w których się wychowywali. Zakres wieloaspektowych badań, których częścią jest materiał prezentowany w niniejszym opracowaniu, nie obejmował jednak badania rodziców recydywistów penitencjarnych z uwagi na trudności, a wręcz brak możliwości dotarcia do nich. Ponadto, analizy badawcze zostały ukierunkowane na przyczyny porażki readaptacyjnej w percepcji osób, które jej bezpośrednio doświadczyły, stąd też dane dotyczące rodzin pochodzenia zostały uzyskane w wyniku retrospektywnego opisu dokonanego przez badanych recydywistów. Wobec powyższego, w dalszej części artykułu zostaną zaprezentowane jedynie powiązania między wybranymi zmiennymi. Pełen obraz rodzin pochodzenia osób niedostosowanych społecznie oraz uwikłanych w działania przestępcze (dominujące cechy rodziców oraz funkcjonowanie rodziny jako całości) znajduje się w opisie moich wcześniejszych badań nad rodzinami wieloproblemowymi (Nowak, 2011).

W badaniu zastosowałam Skalę do Pomiaru Poczucia Umiejscowienia Kontroli - Skala I-E (Inter-External Scale) J.B. Rottera w przekładzie Ł. Drwala. Jest to skala typu Likerta, na którą składa się 29 par zdań, z czego 6 stanowi pozycje buforowe, pozostałe 23 mierzą poczucie kontroli w ten sposób, że wysoki wynik świadczy o zewnętrznym poczuciu kontroli, a niski o wewnętrznym. Dane dotyczące rodzin pochodzenia badanych recydywistów zostały pozyskane z kwestionariusza ankiety konstrukcji własnej.

W badaniu uczestniczyło 245 recydywistów penitencjarnych wyłonionych w celowo-losowym schemacie doboru próby badawczej, osadzonych w dwu typach zakładów karnych dla recydywistów - typu półotwartego w Żytkowicach (110 osadzonych) i typu zamkniętego w Siedlcach (135 osadzonych). 
Wśród uczestników badania znajdowali się recydywiści jednokrotni (137 osób) oraz wielokrotni (108 osób), odbywający terminową karę izolacji więziennej, w tym, krótkoterminową - 89 osadzonych, średnioterminową - 99 osób oraz długoterminową - 44 osoby $^{2}$. Na wolności, najczęstszym miejscem zamieszkania osób badanych było miasto do 100 tys. mieszkańców (101 recydywistów). Z kolei mieszkańcami dużych miast (powyżej 100 tys. mieszkańców) było 88 badanych, zaś na wsi zamieszkiwało 56 osób. Badani recydywiści to w zdecydowanej większości osoby w średnim wieku (31-40 lat; 100 osób) oraz młode (21-30 lat; 65 osób). Pozostali, to recydywiści starsi, lokujący się w przedziale wiekowym od 41 do 55 lat (44 osoby) oraz powyżej 55 lat (24 osoby). Wśród ogółu osób badanych najliczniejsi byli kawalerowie (53\%). Osoby rozwiedzione stanowiły $26 \%$, zaś najmniej liczni byli osadzeni znajdujący się w związkach formalnych lub nieformalnych $(21 \%)^{3}$. Zdecydowana większość recydywistów legitymowała się niskim poziomem wykształcenia $(76,0 \%)$, w tym edukację szkolną na etapie podstawowym zakończyło 77 osadzonych, zaś na poziomie gimnazjalnym 27 osób. Przygotowanie zawodowe uzyskały 83 osoby. Szkołę średnią (liceum lub technikum) ukończyło 22,0\% ogółu badanych recydywistów, zaś wyższy poziom wykształcenia posiadało jedynie $2,0 \%$ osadzonych.

Należy podkreślić, że zaprezentowane wyniki badania są obciążone subiektywną oceną badanych recydywistów i związanymi z tym zniekształceniami atrybucyjnymi. Są one aktywowane przez zaistnienie sytuacji nietypowych (Meyer, Reisenzein, Schützwohl, 1997, s. 258), do których należy również izolacja więzienna. Można oczywiście dyskutować, czy sytuacje wielokrotnego uwięzienia są nietypowe czy też typowe dla osoby izolowanej, ale w tych rozważaniach należy pamiętać zarówno o negatywnych skutkach izolacji więziennej, jak i o tym, że wolność jest jedną z najbardziej fundamentalnych i uniwersalnych wartości zarówno dla jednostki, wspólnoty rodzinnej, jak i narodu. W tym kontekście (re)adaptacja do warunków więziennych nie zmienia sytuacji izolacji, która skutkuje fizycznym i psychicznym zniewoleniem osób osadzonych.

2 Terminowa kara pozbawienia wolności wymieniona w art. 32 pkt 3 k.k., trwa najkrócej miesiąc, najdłużej 15 lat. Wymierzana jest w miesiącach i latach. Wymiar kary krótkoterminowej wynosi od 1 miesiąca do 6 miesięcy, natomiast w Rekomendacji Rady Europy z 2003 roku za karę długoterminową przyjmuje się karę powyżej 5 lat pozbawienia wolności, wymierzaną za poważne przestępstwa kryminalne (agresji, przemocy, a także niezwykle poważnego zagrożenia życia i zdrowia ludzkiego).

${ }^{3}$ Podobne dane uzyskali T. Szymanowski oraz I. Rzeplińska (Szczepanik, 2015, s. 29). 


\section{Poczucie umiejscowienia kontroli u recydywistów penitencjarnych}

U zdecydowanej większości badanych recydywistów, niezależnie od poziomu ich wykształcenia, miejsca zamieszkania oraz typu rodziny pochodzenia (pełna/niepełna), występuje LOC zewnętrzny ( $92,7 \%$ ogółu osób badanych), co umacnia wyniki badań K. Strzelczyk i K. Belniak. Interesujące jest natomiast, że pomimo braku statystycznie istotnej zależności, czterokrotnie większy odsetek recydywistów osadzonych w zakładzie zamkniętym legitymuje się LOC wewnętrznym $(12,6 \%)$, w porównaniu z osadzonymi w zakładzie półotwartym (3,1\%). Przypuszczalnie przyczyną takiego stanu rzeczy jest to, że w zakładzie typu zamkniętego występuje większe nasilenie aktywności podkulturowej, a jak sugerują wyniki badań K. Belniak, osoby włączone do podkultur więziennych wykazują większe nasilenie wewnętrznego poczucia kontroli. Potwierdzony został także brak istotnych związków między poczuciem umiejscowienia kontroli u osób powracających do przestępstwa a wielokrotnością recydywy. Świadczy to o słabej dynamice zmian w obrębie tego wymiaru osobowości u wielokrotnych przestępców, a tym samym o nieskuteczności oddziaływań resocjalizujących prowadzonych w trakcie ich osadzenia, co w konsekwencji prowadzi do porażki readaptacyjnej skutkującej powrotem do przestępstwa.

\section{Typ rodziny i postrzeganie postaw wychowawczych rodziców a poczucie umiejscowienia kontroli u badanych recydywistów}

Nie odnotowano istotnej statystycznie zależności między umiejscowieniem kontroli a typem rodziny pochodzenia recydywistów. $Z$ uwagi na deklaratywne pozyskanie danych dotyczących rodzin pochodzenia, w przedmiotowym badaniu nie identyfikowano istotności statystycznej pomiędzy poczuciem lokalizacji kontroli u osób badanych a postawami wychowawczymi ich rodziców. Należy jednak podkreślić, że rozpatrywane zagadnienie jest bardzo istotne z pedagogicznego i społecznego punktu widzenia i wymaga podjęcia dalszych, pogłębionych badań empirycznych.

W odniesieniu do postrzegania przez osoby badane postaw wychowawczych ich rodziców, odnotowano niewielkie różnice międzygrupowe (tabela nr 1). W grupie osób z LOC zewnętrznym dominujące okazały się dwie postawy wychowawcze: „letnia” (obojętno-odrzucająca) i „chwiejna” (oddziaływanie niekonsekwentne). Z kolei recydywiści posiadający LOC wewnętrzny, najczęściej postrzegali swoich rodziców jako osoby dyscyplinujące i karzące 
(postawa wychowawcza „zimna”). Należy podkreślić, że postawy rodzicielskie obojętno-odrzucające i niekonsekwentne oddziaływanie, kształtują u dzieci poczucie osamotnienia, krzywdy i niesprawiedliwości. Dzieci te są częściej niedostosowane społecznie, wycofane, bezradne, zdane na przypadkowe zrządzenia losu. Równie niekorzystna wychowawczo jest „zimna”, dyscyplinująco-karząca postawa rodzicielska.

Tab. 1. Umiejscowienie kontroli u osób badanych a postawy wychowawcze ich rodziców

\begin{tabular}{|l|c|c|c|c|c|}
\hline \multicolumn{1}{|c|}{ Postawa } \\
\hdashline $\begin{array}{c}\text { Umiejscowienie } \\
\text { kontroli }\end{array}$ & $\begin{array}{c}\text { DYSCYPLINUJACO- } \\
\text { KARZACA }\end{array}$ & $\begin{array}{c}\text { OBOJĘTNO- } \\
\text { ODRZUCAJACA } \\
\text { („zimna") }\end{array}$ & $\begin{array}{c}\text { KOCHAJACO- } \\
\text { WYROZUMIALA } \\
\text { („letnia") }\end{array}$ & $\begin{array}{c}\text { NIEKONSEKWENTNE } \\
\text { ODDZIALYWANIE }\end{array}$ & Ogółem \\
(„gorąca") & („chwiejna”) & \\
\hline LOC & $\mathrm{N}=3$ & $\mathrm{~N}=2$ & $\mathrm{~N}=7$ & $\mathrm{~N}=3$ & $\mathrm{~N}=15$ \\
wewnętrzny & $12,5 \%$ & $5,3 \%$ & $9,2 \%$ & $5,0 \%$ & $7,6 \%$ \\
\hline LOC & $\mathrm{N}=21$ & $\mathrm{~N}=36$ & $\mathrm{~N}=69$ & $\mathrm{~N}=57$ & $\mathrm{~N}=183$ \\
zewnętrzny & $87,5 \%$ & $94,7 \%$ & $90,8 \%$ & $95,0 \%$ & $92,4 \%$ \\
\hline Razem & $\mathrm{N}=24$ & $\mathrm{~N}=38$ & $\mathrm{~N}=76$ & $\mathrm{~N}=60$ & $\mathrm{~N}=198$ \\
& $100,0 \%$ & $100,0 \%$ & $100,0 \%$ & $100,0 \%$ & $100,0 \%$ \\
\hline
\end{tabular}

Zaskakujące okazały się natomiast pozytywne i dosyć silne (przy tym istotne statystycznie) związki pomiędzy poszczególnymi indeksami postaw wychowawczych rodziców wobec osób badanych. Oznacza to, że respondenci wskazujący na stosowanie wobec nich postaw jednego typu, mieli też tendencję do wskazywania, iż stosowane były wobec nich również zachowania charakterystyczne dla innych postaw. Najprawdopodobniej jest to jednak artefakt badawczy związany z tym, że osadzeni bardzo różnili się między sobą co do ogólnej skłonności udzielania odpowiedzi twierdzących na pytania określające te postawy.

\section{Postrzeganie przez recydywistów ich relacji z rodzicami}

Ponad połowa ogółu badanych recydywistów utrzymywała i nadal utrzymuje bardzo dobre relacje z rodzicami (tabela $\mathrm{nr} 2$ ). Osoby legitymujące się wykształceniem podstawowym, w porównaniu z osobami posiadającymi wyższy poziom wykształcenia (we wszystkich kategoriach), najrzadziej deklarowały złe relacje z rodzicami lub przerwanie z nimi kontaktu. Jest to zależność istotna statystycznie, wskazująca, iż im wyższy poziom wykształcenia posiada osoba 
badana, tym jej relacje z rodzicami są gorsze. Być może trudności komunikacyjne i relacyjne wynikają $\mathrm{w}$ tym przypadku z rozbieżności pomiędzy poziomami wykształcenia rodziców i dzieci, bowiem ponad 2/3 rodziców badanych recydywistów $(68,3 \%)$ posiadało niski poziom wykształcenia (podstawowy i zawodowy).

Tab. 2. Relacje z rodzicami a poziom wykształcenia badanych recydywistów

\begin{tabular}{|l|c|c|c|c|c|}
\hline \multicolumn{1}{|c|}{$\begin{array}{c}\text { Poziom wykształcenia } \\
\text { Relacje z rodzicami }\end{array}$} & $\begin{array}{c}\text { Podstawo- } \\
\text { we }\end{array}$ & Gimnazjalne & Zawodowe & $\begin{array}{c}\text { Średnie } \\
\text { i wyższe }\end{array}$ & Ogółem \\
\hline $\begin{array}{l}\text { bardzo dobre, zawsze się } \\
\text { świetnie dogadywaliśmy, dalej } \\
\text { mamy dobry kontakt }\end{array}$ & $\begin{array}{c}\mathrm{N}=45 \\
68,2 \%\end{array}$ & $\begin{array}{c}\mathrm{N}=9 \\
37,5 \%\end{array}$ & $\begin{array}{c}\mathrm{N}=40 \\
55,6 \%\end{array}$ & $\begin{array}{c}\mathrm{N}=23 \\
45,1 \%\end{array}$ & $\begin{array}{c}\mathrm{N}=117 \\
54,9 \%\end{array}$ \\
\hline kiedyś były dobre, ale teraz \\
nasze stosunki się pogorszyły & $\mathrm{N}=16$ & $\mathrm{~N}=9$ & $\mathrm{~N}=14$ & $\mathrm{~N}=17$ & $\mathrm{~N}=56$ \\
\hline złe, nie utrzymuję kontaktów & $\mathrm{N}=5$ & $\mathrm{~N}=6$ & $\mathrm{~N}=18$ & $\mathrm{~N}=11$ & $\mathrm{~N}=40$ \\
z rodzicami & $7,6 \%$ & $25,0 \%$ & $25,0 \%$ & $21,6 \%$ & $18,8 \%$ \\
\hline Razem & $\mathrm{N}=66$ & $\mathrm{~N}=24$ & $\mathrm{~N}=72$ & $\mathrm{~N}=51$ & $\mathrm{~N}=213$ \\
& $100,0 \%$ & $100,0 \%$ & $100,0 \%$ & $100,0 \%$ & $100,0 \%$ \\
\hline
\end{tabular}

Test niezależności chi-kwadrat. Wartość statystyki testowej wynosi 14,44 przy 6 stopniach swobody. Hipoteza o braku związku pomiędzy analizowanymi zmiennymi może zostać odrzucona na poziomie istotności 0,025 - mamy zatem do czynienia ze statystycznie istotną zależnością.

W odniesieniu do typu zakładu karnego okazało się, że osadzeni w zakładzie półotwartym istotnie częściej utrzymują bardzo dobre relacje z rodzicami niż osadzeni z zakładu zamkniętego ${ }^{4}$. Jest to prawdopodobnie spowodowane tym, że wychodząc stosunkowo często na przepustki, recydywiści z zakładu półotwartego mają okazję do podtrzymywania dobrych relacji z rodziną. A być może w sytuacji, gdy osoba bliska zostaje skazana za poważne przestępstwo kryminalne (agresji, przemocy lub niezwykle poważnego zagrożenia dla życia i zdrowia ludzkiego) jest to efekt dystansowania się od niej pozostałych członków rodziny, zwłaszcza, że zarówno ona, jak i rodzina nosząca piętno jej przestępstwa jest negatywnie postrzegana społecznie i stygmatyzowana środowiskowo.

${ }^{4}$ Przeprowadzono test niezależności chi-kwadrat. Wartość statystyki testowej wyniosła 12,43 przy 2 stopniach swobody. Hipoteza o braku związku pomiędzy analizowanymi zmiennymi może zostać odrzucona na poziomie istotności 0,002 . 


\section{Sytuacja materialna rodzin pochodzenia w percepcji osób badanych}

W rodzinach pełnych wychowywało się ponad 2/3 badanych recydywistów. W większości przypadków osadzeni wskazywali jednak na wielorakie trudności w funkcjonowaniu rodzin pochodzenia, co prawdopodobnie mogło przyczynić się do ukształtowania się u nich zewnętrznego umiejscowienia kontroli (wynik spójny z cytowanym badaniem K. Strzelczyk). Były to bowiem rodziny dysfunkcyjne i/lub patologiczne, w których praźródłem problemów było najczęściej bezrobocie i związane z nim ubóstwo. Badani doszukiwali się również powiązań takiego stanu rzeczy z niskim poziomem wykształcenia rodziców, brakiem ich przygotowania zawodowego i umiejętności poszukiwania pracy, jak i możliwościami uzyskania stałego zatrudnienia oraz obecnością czynników patologizujących (najczęściej wskazywano na przemoc w rodzinie oraz chorobę alkoholową). Świadczy to o niskim poziomie kompetencji życiowych rodziców badanych recydywistów, co jest zgodne z wynikiem cytowanego badania L. Contrerasa et al., wskazującego na powiązania zewnętrznej lokalizacji kontroli z dysfunkcją/patologią środowiska rodzinnego oraz objawami nieprzystosowania społecznego, jak również z wynikami moich badań nad rodzinami wieloproblemowymi.

W świetle powyższego interesujące jest to, że w zdecydowanej większości przypadków osoby badane postrzegały sytuację materialną rodziny pochodzenia jako stabilną: dobrą lub wystarczającą (tabela nr 3). Zatem wedle tych deklaracji, większość rodzin badanych recydywistów nie powinna otrzymywać wspomagania zewnętrznego, a jednak w świetle danych zaprezentowanych w tabeli $\mathrm{nr} 4$, takie wsparcie otrzymywało $2 / 3$ ich rodzin pochodzenia.

Tab. 3. Typ rodziny pochodzenia a sytuacja materialna rodziny w ocenie osób badanych

\begin{tabular}{|l|c|c|c|}
\hline $\begin{array}{c}\text { Typ rodziny pochodzenia } \\
-\begin{array}{c}\text { Ocena sytuacji } \\
\text { materialnej rodziny }\end{array}\end{array}$ & Rodzina pełna & Rodzina niepełna & Ogółem \\
\hline \multirow{2}{*}{ bardzo dobra } & $\mathrm{N}=27$ & $\mathrm{~N}=13$ & $\mathrm{~N}=40$ \\
\hline \multirow{2}{*}{ dobra } & $17,1 \%$ & $15,7 \%$ & $16,6 \%$ \\
\hline \multirow{2}{*}{ wystarczająca } & $\mathrm{N}=49$ & $\mathrm{~N}=16$ & $\mathrm{~N}=65$ \\
& $31,0 \%$ & $19,3 \%$ & $27,0 \%$ \\
\hline
\end{tabular}


Tab. 3. Typ rodziny pochodzenia a sytuacja materialna rodziny w ocenie osób badanych, cd.

\begin{tabular}{|l|c|c|c|}
\hline $\begin{array}{c}\text { Typ rodziny pochodzenia } \\
\text { Ocena sytuacji } \\
\text { materialnej rodziny }\end{array}$ & Rodzina pełna & Rodzina niepełna & Ogółem \\
\hline \multirow{2}{*}{ zła } & $\mathrm{N}=27$ & $\mathrm{~N}=24$ & $\mathrm{~N}=51$ \\
& $17,1 \%$ & $28,9 \%$ & $21,2 \%$ \\
\hline \multirow{2}{*}{ bardzo zła } & $\mathrm{N}=4$ & - & $\mathrm{N}=4$ \\
& $2,5 \%$ & $0,0 \%$ & $1,7 \%$ \\
\hline \multirow{2}{*}{ Razem } & $\mathrm{N}=158$ & $\mathrm{~N}=83$ & $\mathrm{~N}=241$ \\
& $100,0 \%$ & $100,0 \%$ & $100,0 \%$ \\
\hline
\end{tabular}

Można przypuszczać, że albo badani recydywiści opisywali swoje rodziny w lepszym świetle, niż to było w rzeczywistości (osoby z LOC zewnętrznym mają tendencje do myślenia życzeniowego i fantazjowania, co udowodniły cytowane badania J.E. Terelak i M. Steckiewicz), albo część rodzin pochodzenia nie wykazywała faktycznych dochodów (ukrywała je). Oba przypuszczenia wydają się uzasadnione, zwłaszcza, gdy weźmiemy pod uwagę naturalną skłonność człowieka do zawyżania opinii dotyczących jego samego i osób mu bliskich oraz fakt, że rodziny pochodzenia osób badanych funkcjonowały w trudnym okresie transformacji ustrojowej, kiedy to zawirowania gospodarczo-ekonomiczne generowały wiele niekorzystnych zjawisk społecznych. Dochodziło wówczas do licznych nadużyć związanych z pomocą społeczną. Ponadto, nasilone zjawisko czasowej emigracji zarobkowej z jednej strony owocowało polepszaniem się sytuacji materialnej rodzin migracyjnych, zaś z drugiej powodowało destabilizację ich systemów (zwłaszcza w sferze relacyjnej), a w wielu przypadkach skutkowało ich destrukcją.

Niesprawność funkcjonowania własnych rodzin pochodzenia, przejawiającą się korzystaniem przez rodziców z usług instytucji pomocowych, badani recydywiści wiązali z różnorodnymi przyczynami. Najczęściej wskazywane było przez nich bezrobocie i ubóstwo rodziny (dotkniętych nimi było prawie $2 / 3$ rodzin), powiązane $z$ :

- niskim poziomem wykształcenia rodziców $(68,3 \%$ legitymowało się wykształceniem podstawowym i zawodowym, 25,8\% średnim, a wyższym jedynie 5,9\%);

- niskim poziomem kompetencji życiowych rodziców (sprawności komunikacyjnych i umiejętności radzenia sobie w sytuacjach trudnych);

- trudnościami w utrzymaniu stałej pracy (niski poziom kwalifikacji za- 
wodowych) oraz cechami osobowymi, utrudniającymi im wykonywanie obowiązków służbowych, takimi jak: lenistwo, wygodnictwo, brak rzetelności czy odpowiedzialności).

- chorobą alkoholową jednego z rodziców (najczęściej ojca).

Uzależnienie, głównie od alkoholu było czynnikiem patologizującym życie ponad połowy rodzin pochodzenia badanych recydywistów. Okazało się, że istnieje zależność (na poziomie istotności równym 0,042), pomiędzy występowaniem problemu uzależnień a wielkością miejscowości zamieszkania rodziny pochodzenia. Problemem tym dotknięte były najczęściej rodziny mieszkające $\mathrm{w}$ dużych miastach (59,8\% z grupy rodzin wielkomiejskich), zaś najrzadziej rodziny żyjące na wsi (35,7\% z grupy rodzin wiejskich). Im mniejsza była zatem miejscowość zamieszkania rodziny, tym rzadziej występowała w niej choroba alkoholowa.Po pomoc instytucjonalną sięgały istotnie częściej rodziny pochodzenia niepełne niż pełne (tabela $\mathrm{nr} 4$ ).

Zastanawiająca jest względna samodzielność funkcjonowania rodzin niepełnych, tym bardziej, gdy weźmiemy pod uwagę fakt, że większość ogółu rodzin pochodzenia badanych recydywistów funkcjonowała w państwie opiekuńczym, które szczególnym wsparciem otaczało właśnie rodziny tego typu, a zwłaszcza samotne matki. Można jedynie przypuszczać, że samotni rodzice nie korzystający z pomocy instytucjonalnej, w większym stopniu niż rodzice tworzący pełne wspólnoty rodzinne, wspomagani byli przez bliskich krewnych lub opierali się na własnej zaradności.

Tab. 4. Typ rodziny pochodzenia a wsparcie instytucji pomocowych

\begin{tabular}{|l|c|c|c|}
\hline $\begin{array}{c}\text { Typ rodziny pochodzenia } \\
\text { Wsparcie instytucjonalne }\end{array}$ & Rodzina pełna & Rodzina niepełna & Ogółem \\
\hline $\begin{array}{l}\text { Rodzinie udzielane były } \\
\text { świadczenia pomocowe }\end{array}$ & $\mathrm{N}=97$ & $\mathrm{~N}=35$ & $\mathrm{~N}=132$ \\
\hline Rodzina nie korzystała & $\mathbf{7 0 , 3} \%$ & $52,2 \%$ & $64,4 \%$ \\
z pomocy społecznej & $\mathrm{N}=41$ & $\mathrm{~N}=32$ & $\mathrm{~N}=73$ \\
\hline Razem & $29,7 \%$ & $47,8 \%$ & $35,6 \%$ \\
\hline & $\mathrm{N}=138$ & $\mathrm{~N}=67$ & $\mathrm{~N}=205$ \\
& $100,0 \%$ & $100,0 \%$ & $100,0 \%$ \\
\hline
\end{tabular}

Test niezależności chi-kwadrat. Wartość statystyki testowej 6,41 przy 1 stopniu swobody. Hipoteza o braku związku pomiędzy analizowanymi zmiennymi może zostać odrzucona na poziomie istotności 0,011 - odnotowano zależność istotną statystycznie. Korelacja Pearsona: $r=0,177$

Ponad połowa rodziców badanych recydywistów nie podejmowała dodatkowych wysiłków w celu polepszenia dobrostanu rodzinnego $(55,0 \%)$. Jeże- 
li już decydowali się oni na podjęcie aktywności zmierzającej do polepszenia materialnych warunków życia rodziny, to najczęściej wykonywali dodatkową pracę etatową $(52,7 \%)$. Z kolei prace dorywcze wykonywali częściej rodzice osadzonych w zakładzie zamkniętym $(41,9 \%)$ niż w półotwartym $(13,3 \%)^{5}$. Istotnie częściej bierni byli $\mathrm{w}$ tym zakresie rodzice tworzący rodziny pełne $(38,6 \%)$ niż niepełne $(57,8 \%)^{6}$. Wzmacnia to wyrażone wyżej przypuszczenie o lepszym radzeniu sobie z problemami samotnych rodziców. Wyniki badania w tym zakresie są spójne z wynikami moich wcześniejszych badań nad rodziną w kryzysie wieloproblemowym (Nowak, 2011). Wówczas uzyskałam podobny obraz rodzin pełnych, w których rodzice naznaczeni byli niemocą i bezsilnością w obliczu pojawiających się problemów, a których praźródło stanowiło właśnie bezrobocie i wiążące się z nim ubóstwo.

\section{Podsumowanie}

Wyniki badania zaprezentowane w niniejszym opracowaniu ugruntowują tezę o zewnętrznym ulokowaniu sprawstwa zdarzeń u recydywistów penitencjarnych. Nie można jednak stwierdzić, że jest to wyłącznie efekt długotrwałego lub częstego ich przebywania w środowisku zamkniętym, gdyż na poczucie umiejscowienia kontroli mają istotny wpływ również inne, nieizolacyjne czynniki środowiskowe, w tym rodzinne. Można zatem przypuszczać, że zewnętrzne umiejscowienie poczucia kontroli u recydywistów penitencjarnych jest powiązane zarówno z ich (re)adaptacją do warunków izolacyjnych, jak i z niekorzystnym splotem uwarunkowań wychowania rodzinnego. Rodziny pochodzenia badanych recydywistów są bowiem najczęściej pełne, ale wieloproblemowe i posiadające cechy, które mogły być przyczyną ukształtowania się u dzieci zewnętrznego poczucia umiejscowienia kontroli (m.in. bezrobocie, ubóstwo, choroba alkoholowa w rodzinie oraz bezradność lub bierność rodziców w obliczu kumulujących się problemów). Te wyniki badania potwierdzają zasadność objęcia rodzin z problemem penitencjarnym wspomaganiem nie

${ }^{5} \mathrm{~W}$ analizie statystycznej zastosowano test niezależności chi-kwadrat. Wartość statystyki testowej 10,23 przy 2 stopniach swobody, co pozwala na odrzucenie hipotezy o braku związku pomiędzy analizowanymi zmiennymi, na poziomie istotności 0,006 - oznacza to, że mamy do czynienia ze statystycznie istotną zależnością.

${ }^{6} \mathrm{~W}$ analizie statystycznej zastosowano test niezależności chi-kwadrat. Wartość statystyki testowej wyniosła 6,36 przy 1 stopniu swobody. Ustalono, że hipoteza o braku związku pomiędzy analizowanymi zmiennymi może zostać odrzucona na poziomie istotności 0,012 . Oznacza to, że występuje statystycznie istotna zależność (korelacja Pearsona: $\mathrm{r}=-0,182$ ). 
tylko socjalnym, ale przede wszystkim kompetencyjnym, na co wskazywałam wielokrotnie w moich dotychczasowych publikacjach (m.in. Nowak, 2014; 2016; 2016a). Ponadto, dwie postawy rodzicielskie: „letnia” (obojętno-odrzucająca) i „,chwiejna” (oddziaływanie niekonsekwentne) okazały się dominujące u rodziców badanych recydywistów. Może to skłaniać do sformułowania postulatu, że w programach oddziaływań resocjalizujących ważne miejsce zająć powinny oddziaływania $\mathrm{w}$ zakresie kształtowania postaw rodzicielskich oraz warsztaty umiejętności wychowawczych. Pożądane jest również podjęcie oddziaływań profilaktycznych, psychoedukacyjnych i resocjalizujących, ukierunkowanych na reorientację u recydywistów penitencjarnych LOC zewnętrznego na LOC wewnętrzny. Wprawdzie uwarunkowania pozytywnej readaptacji społecznej są wielorakie i złożone, ale skazani poddani tego typu oddziaływaniom po zakończeniu odbywania kary izolacji więziennej mogliby być prawdopodobnie bardziej sprawni w podejmowaniu samodzielnych i konstruktywnych działań readaptacyjnych. Ponadto w programach przygotowujących osadzonych do wyjścia na wolność ważne miejsce zająć powinny warsztaty kształtowania pożądanych wychowawczo postaw rodzicielskich i umiejętności wychowawczych.

Na zakończenie pragnę podkreślić, że zagadnienie rodzinnych uwarunkowań krystalizacji poczucia umiejscowienia kontroli powinno być rozpatrywane w oparciu o wyniki wieloaspektowych badań longitudinalnych. Umożliwiłyby to prześledzenie również innych środowiskowych determinantów poczucia lokalizacji kontroli na kolejnych etapach rozwoju osobniczego. Interesujące byłyby także badania porównawcze: młodzieży zagrożonej niedostosowaniem społecznym (np. wychowanków MOS-ów), młodzieży niedostosowanej społecznie (wychowanków MOW-ów), nieletnich przestępców osadzonych w zakładach poprawczych oraz osadzonych w zakładach karnych po raz pierwszy i kolejny. W takim układzie generacyjnym i przy coraz bardziej dotkliwym ograniczeniu wolności, można byłoby prześledzić etiologię i dynamikę zmian w poczuciu umiejscowienia kontroli u osób niedostosowanych społecznie i podejmujących zachowania przestępcze. Dostrzegam też potrzebę podjęcia badań nad skutecznością kary izolacji więziennej, obejmujących poszukiwanie powiązań między poczuciem umiejscowienia kontroli u recydywistów i środowiskowymi uwarunkowaniami jego kształtowania się (izolacyjnymi i nieizolacyjnymi) a wymiarem zasądzonej kary i okresem jej faktycznej realizacji. 


\section{Bibliografia:}

Andreou E. (2000). Bully /Victim Problems and Their Association With Psychological Constructs in 8-to 12-Year-Old Greek Schoolchildren. Aggressive Behavior, Vol. 26, s. $49-56$.

Bandura A. (1977). Self-efficacy: Toward a Unifying Theory of Behavioral Change Psychological Review, nr 2.

Barnow S., Schuckit M.A., Lucht M. i in. (2002). The Importance of e Positive Family History of Alcoholism, Parental Rejection and Emotional Warmth, Behavioral Problems and Peer Substance Use of Alcohol Problems in Teenagers: A Path Analysis. Journal of Studies on Alcohol, 63, s. 305-316.

Belniak K. (2014). Poczucie kontroli u sprawców przestępstw agresywnych. Acta Univesitatis Lodiensis, $\mathrm{nr} 18$.

Blatier C. (2000). Locus of Control, Casual Attributions and Self-Esteem: A Comparison Between Prisoners. International Journal of Offender Therapy and Comparative Criminology, vol. 44, nr 1, s. 97-110.

Borecka-Bernat D. (2014). Osobowościowe determinanty agresywnej strategii rozwiązywania konfliktów przez gimnazjalistów. Szkoła Specjalna, nr 4.

Bowen E., Gilchrist E. A., Beech A. (2005). An examination of the impact of community based rehabilitation on the offending behavior of Male domestic Violence offenders and the characteristics associated with recidivism. Legal and Criminological Psychology, vol. 10, s. 189-209.

Bowen E., Gilchrist E.A. (2004). Do court - and self-reffered domestic violence offenders share the same characteristic? A preliminary comparison of motivation to change, locus of control and anger. Legal and Criminological Psychology, vol.9, s. 279-294.

Capaldi D.M., Pears K.C., Kerer D.R., Owen L.D. (2008). Intergenerational and Partner Influence on Father's Negative Discipline. Journal Abnormal Child Psychology, 36, s. $347-358$.

Chaim W. (1996). Umiejscowienie poczucia kontroli a nasilenie potrzeb, lęku i mechanizmów obronnych. Studia Philosophiae Christianae, nr 32/2, s. 275-283.

Contreras L., Molina V., Cano M. C. (2011). In search of psychosocial variables linked to the recidivism in young offenders. The European Journal of Psychology Applied to Legal Context, 3, s. 77-88.

Davis C. (2007). At-Risk Girls and Delinquency: Career Pathways. Crime Delinquency, 53, s. $408-435$. 
Horner K.L. (1996). Locus of control, neuroticism, and stressors: combined influences on reported physical illness. Personality Individual Differences, 21 (2), s. 195-204.

Kościelak R. (2010). Poczucie umiejscowienia kontroli i przekonania o własnej skuteczności $w$ zdrowiu i chorobie. Kraków: Oficyna wydawnicza „Impuls”.

Krasowicz G., Kurzyp - Wojnarska A. (1987). Wyznaczniki poczucia kontroli następstw zdarzeń. Psychologia Wychowawcza, nr 5.

Lobo Antunes M. J., Ahlin E. M. (2014). Family management and youth violence: Are parents or community more salient? Journal of Community Psychology, 42, s. 316-337.

Maqsud M. (1980), The relationship of sense of powerlessness to antisocial behavior and school achievement. The Journal of Psychology, nr 105, s. 147-150.

Maier S.F., Seligman M.E. (1976). Learned helplessness: Theory and evidence. Journal of Experimental Psychology: General, 105, s. 3-46.

Meyer W.U., Reisenzein R., Schützwohl A. (1997). Toward a Process Analysis of Emotions: The Case of Surprise. Motivation and Emotion, 21(3), s. 254-274.

Nowak B.M. (2016). Wychodzenie rodziny wieloproblemowej z zapaści kryzysowej. Social Pathology and Prevention, $\mathrm{nr} 4$.

Nowak B.M. (2016a). An innovative training programme for the staff of social integration and assistance institutions, supporting their professional qualifications for working with persons at risk of social exclusion. W: I. Niewiadomska, W. Augustynowicz (red.). Inclusion - psychosocial aspects. Psychoprevention studies. Lublin: Wyd. Natanaelum.

Nowak B.M., Krawczyk J. (2014). Social skills and locus of control of teenage mothers and pregnant teens placed at the Polish Correctional Institutions. Report of studies. International Letters of Social and Humanistic Sciences, 12, s. 7-22.

Nowak B.M. (2014). Od kreacji do autokreacji rodziny. model oddziaływań stabilizująco rozwojowych wobec rodziny w kryzysie wieloproblemowym. W: M. Kolankiewicz, B.M. Nowak (red.). Rodzina w potrzebie - kierunki wychodzenia z kryzysu. Warszawa: Fundacja Orlen - Dar Serca.

Nowak B.M. (2011). Rodzina w kryzysie. Studium resocjalizacyjne. Warszawa: PWN.

Nowicki S., Strickland B.R. (1973). A Locus Of Control Scale For Children. Journal of Consulting and Clinical Psychology, 40, s. 148-154.

Rotter J.B. (1966). Generalized expectancies for internal versus external control of reinforcement. Psychological Monographs: General and Applied, vol. 80, nr 1 (609), s. 1-28.

Strzelczyk K. (2010). Poczucie kontroli u skazanych uczestniczących w więziennej terapii uzależnień. Studia z Psychologii KUL, tom 16, s. 75-89. 
Szczepanik R. (2015). Stawanie się recydywistą. Kariery instytucjonalne osób powracajacych do przestępczości. Łódź: Wyd. Uniwersytetu Łódzkiego.

Szmigielska B. (1996). Wybrane aspekty rozwoju poznawczego społeczno-emocjonalnego a poczucie kontroli u dzieci. W: M. Smoczyńska (red.). Studia z psychologii rozwojowej i psycholingwistyki. Kraków: Universitas.

Terelak J.F., Steckiewicz M. (2007). Charakterystyka stresu ekologicznego i różnice indywidualne w radzeniu sobie z nim na przykładzie osób przebywających w więzieniu. Studia Ecologiae i Bioethicae, nr 5, s. 23-41.

Thornberry T. P. (2005). Explaining Multiple Patterns of Offending cross the Life Course and cross Generations. The Annals of the American Academy of Political and Social Science, 602, s. 156-196.

Turecka M. (2005). Czynniki zwiększające ryzyko i zapobiegające przemocy seksualnej. Seksuologia Polska, nr 3,2, s. 45-51.

Wallace M.T., Barry C.T., Zeigler- Hill V., Green B.A. (2012). Locus of Control as a Contributing Factor in the Relation Between Self- Perception and Adolescence Aggression. Aggressive Behavior, vol. 38, s. 213-221.

Weiner B. (1985). An Attributional Theory of Achievement Motivation and Emotion, Psychological Review, vol. 92, nr 4, s. 548-573.

Wong P.T.P., Weiner B. (1981). When People Ask "Why" Questions And The Heuristics Of Attribution Search. Journal of Personality and Social Psychology, vol. 40, nr 4, s. $650-663$. 